\title{
Suppressors of RNA Silencing Encoded by the Components of the Cotton Leaf Curl Begomovirus-BetaSatellite Complex
}

\author{
Imran Amin, ${ }^{1}$ Khadim Hussain, ${ }^{1,2}$ Rashid Akbergenov, ${ }^{2}$ Jitender S. Yadav, ${ }^{3}$ Javaria Qazi, ${ }^{1}$ \\ Shahid Mansoor, ${ }^{1}$ Thomas Hohn, ${ }^{2}$ Claude M. Fauquet, ${ }^{3}$ and Rob W. Briddon ${ }^{1}$ \\ ${ }^{1}$ National Institute for Biotechnology and Genetic Engineering, Jhang Road, P.O. Box 577, Faisalabad, Pakistan; ${ }^{2}$ Institute of \\ Botany, University of Basel, Switzerland; ${ }^{3}$ ILTAB/Danforth Plant Science Center, 975 N. Warson Rd, St. Louis 63132, U.S.A.
}

Submitted 6 January 2011. Accepted 7 April 2011.

Begomoviruses (family Geminiviridae) are single-stranded DNA viruses transmitted by the whitefly Bemisia tabaci. Many economically important diseases in crops are caused by begomoviruses, particularly in tropical and subtropical environments. These include the betasatellite-associated begomoviruses causing cotton leaf curl disease (CLCuD) that causes significant losses to a mainstay of the economy of Pakistan, cotton. RNA interference (RNAi) or gene silencing is a natural defense response of plants against invading viruses. In counter-defense, viruses encode suppressors of gene silencing that allow them to effectively invade plants. Here, we have analyzed the ability of the begomovirus Cotton leaf curl Multan virus (CLCuMV) and its associated betasatellite, Cotton leaf curl Multan $\beta$-satellite (CLCuMB) which, together, cause CLCuD, and the nonessential alphasatellite (Cotton leaf curl Multan alphasatellite [CLCuMA]) for their ability to suppress gene silencing in Nicotiana benthamiana. The results showed that CLCuMV by itself was unable to efficiently block silencing. However, in the presence of the betasatellite, gene silencing was entirely suppressed. Silencing was not affected in any way when infections included CLCuMA, although the alphasatellite was, for the first time, shown to be a target of RNA silencing, inducing the production in planta of specific small interfering RNAs, the effectors of silencing. Subsequently, using a quantitative real-time polymerase chain reaction assay and Northern blot analysis, the ability of all proteins encoded by CLCuMV and CLCuMB were assessed for their ability to suppress RNAi and the relative strengths of their suppression activity were compared. The analysis showed that the $\mathrm{V} 2, \mathrm{C} 2, \mathrm{C} 4$, and $\beta \mathrm{C} 1$ proteins exhibited suppressor activity, with the $\mathrm{V} 2$ showing the strongest activity. In addition, $\mathrm{V} 2, \mathrm{C} 4$, and $\beta \mathrm{C} 1$ were examined for their ability to bind RNA and shown to have distinct specificities. Although each of these proteins has, for other begomoviruses or betasatellites, been previously shown to have suppressor activity, this is the first time all proteins encoded by a geminiviruses (or begomovirus-betasatellite complex)

I. Amin and K. Hussain contributed equally to this work.

Current address for R. Akbergenov: Institut für Medizinische Mikrobiologie, Universität Zürich, Gloriastrasse 30/32, 8006 Zürich.

Corresponding author: R. Briddon; Telephone: +92 41 9201804-9201808, ext. 214; E-mail: rob.briddon@gmail.com

* The $\boldsymbol{e}$-Xtra logo stands for "electronic extra" and indicates that a supplementary figure and a supplementary table are published online. have been examined and also the first for which four separate suppressors have been identified.

Geminiviruses are an important group of plant viruses with small circular, single-stranded (ss)DNA genomes that replicate in the nucleus of infected cells (Hanley-Bowdoin et al. 1999). Viruses of the family Geminiviridae are divided into four genera based on insect vectors and genome organization (Stanley et al. 2005). Whitefly-transmitted geminiviruses are classified in the genus Begomovirus. This constitutes the largest genus that includes viruses which cause the greatest economic losses to crops throughout the warmer parts of the world (Stanley et al. 2005; Varma and Malathi 2003). Begomoviruses originating from the New World are bipartite, with genomes consisting of two ssDNA components, known as DNA A and DNA B, of approximately equal size (approximately $2.8 \mathrm{~kb}$ ). Although a few bipartite begomoviruses are known in the Old World, the vast majority are monopartite, with a genome that is a homolog of the DNA A component of the bipartite viruses, and most of these interact with ssDNA satellites (Nawaz-ul-Rehman et al. 2009).

The genomes of monopartite begomoviruses (and DNA-A components of bipartite begomoviruses) encode four genes in the complementary sense and two in the virion sense. The complementary-sense genes encode the replication-associated protein (Rep; the only virus-encoded protein required for viral DNA replication, which is a rolling circle replication initiator protein), the $\mathrm{C} 2$ protein (a homolog of the TrAP protein, which, for bipartite begomoviruses, is involved in upregulating late, virion-sense genes as well as host genes), the replication enhancer (REn; involved, in conjunction with Rep, in creating a cellular environment suitable for virus replication), and the (A)C4 protein, which is involved in host range and symptom determination and may be involved in virus movement. The two virionsense genes encode the coat protein (CP; involved in encapsidation, insect transmission, and movement in plants) and the (A)V2 protein, which may be a pathogenicity determinant and can be involved in virus movement in plants. Characteristically, the DNA A components of New World begomoviruses lack the AV2 gene (Rojas et al. 2005). The DNA B component of bipartite begomoviruses encodes the nuclear shuttle protein in the virion sense and the movement protein in the complementary sense, which are both required for virus movement in plants (Gilbertson et al. 2003).

The monopartite begomoviruses are often experimentally infectious to their natural hosts but do not induce typical symp- 
toms. This group of begomoviruses has been shown to be associated with circular, ss satellite and satellite-like molecules that are half the length of the begomovirus component (Briddon and Stanley 2006). The satellite-like molecules, termed alphasatellites, show homology to the Rep-encoding components of nanoviruses from which they are believed to have evolved following capture, during co-infection, by a begomovirus. Alphasatellites, by virtue of encoding a Rep, are capable of autonomous replication in host plants cells but play no part in symptom induction (Mansoor et al. 1999; Saunders and Stanley 1999). The betasatellites, in contrast, are true satellites and, in many cases, are required by their helper begomoviruses to symptomatically infect the hosts from which they were isolated (Briddon et al. 2001, 2003; Jose and Usha 2003; Saunders et al. 2000). The prime example of such disease complexes is cotton leaf curl disease (CLCuD). CLCuD in Pakistan and northern India is associated with several distinct begomoviruses (at least seven have been reported) (Harrison et al. 1997; Mansoor et al. 1993, 2003a and b). A single species of betasatellite, Cotton leaf curl Multan betasatellite (CLCuMB), was associated with CLCuD regardless of the begomovirus involved (Mansoor et al. 2003a). Inoculation of any of the CLCuDassociated begomoviruses with CLCuMB resulted in induction of typical CLCuD symptoms (Briddon et al. 2001, 2003; Mansoor et al. 2003a and b).

Invading viruses are subjected to a homology-based defense system in plants that is known as RNA interference (RNAi) (also known as RNA silencing and post-transcriptional gene

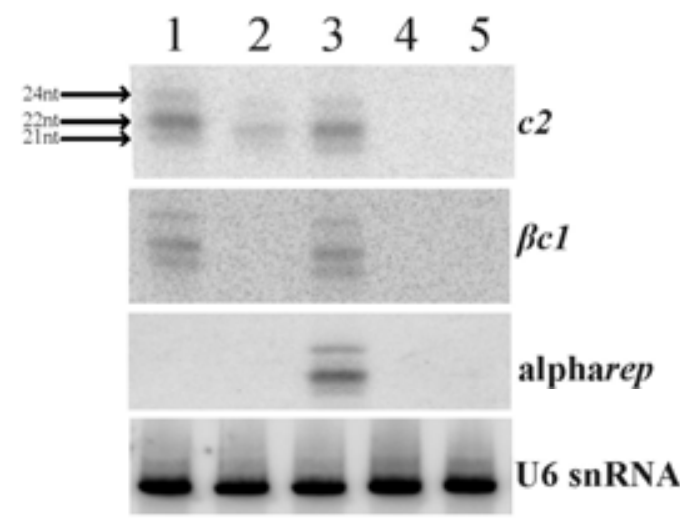

$\begin{array}{llllll}\text { p35S-GFP } & + & + & + & + & - \\ \text { CLCuMV } & + & + & + & - & - \\ \text { CLCuMB } & + & - & + & - & - \\ \text { CLCuMA } & - & - & + & - & -\end{array}$

Fig. 2. All three components of the cotton leaf curl disease (CLCuD) complex are targets for host-mediated silencing. RNA blot hybridizations of 16c plants inoculated with the components of the CLCuD complex, as indicated under the blots, probed for the presence of small-interfering RNAs complimentary to the $c 2$ gene of Cotton leaf curl Multan virus (CLCuMV), the $\beta c 1$ gene of Cotton leaf curl Multan betasatellite (CLCuMB), and the rep gene of Cotton leaf curl Multan alphasatellite (CLCuMA) (alpharep). A separate blot was probed for U6 RNA to act as a loading control.

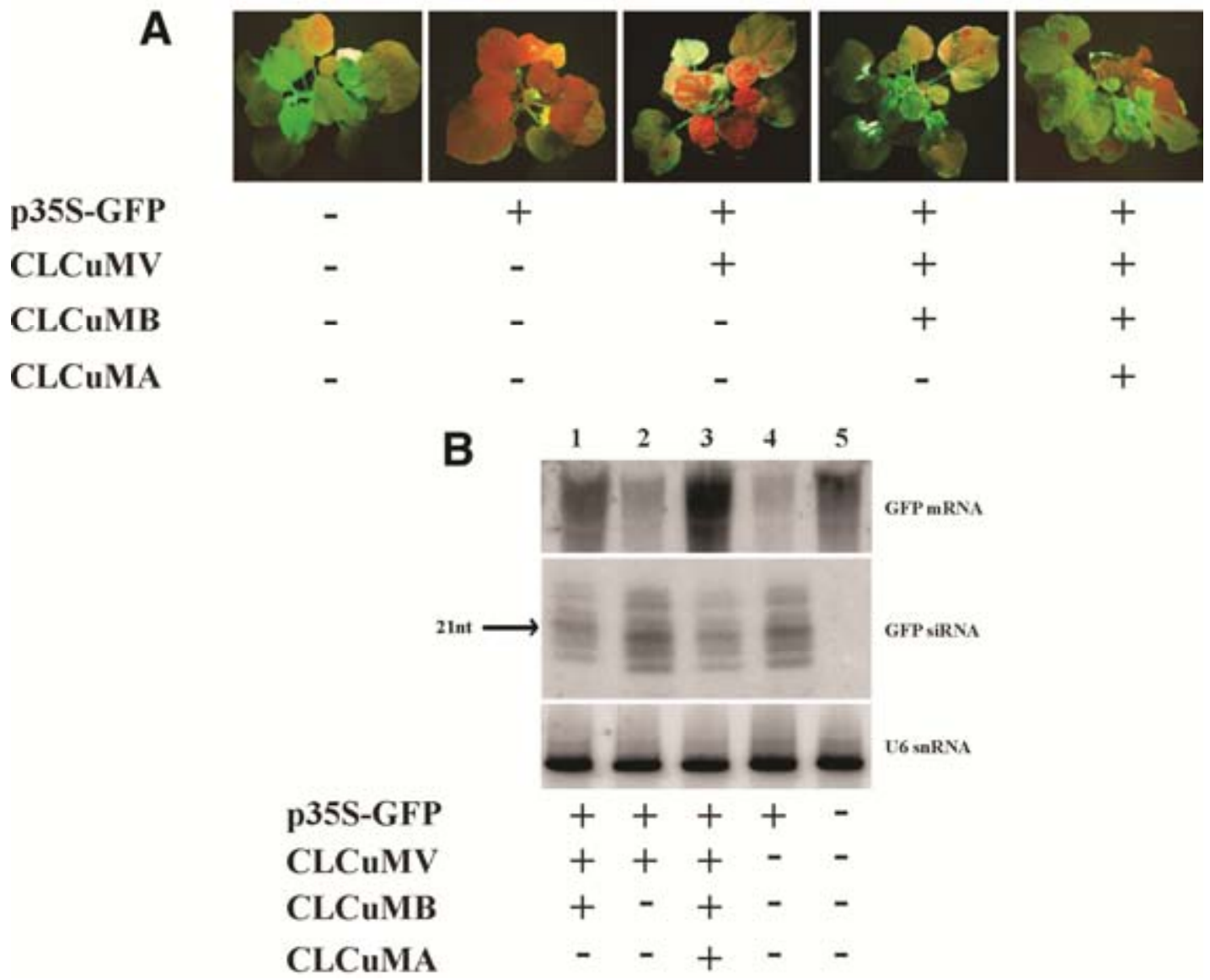

Fig. 1. A, Suppression of gene silencing by the intact components of the cotton leaf curl disease complex. Nicotiana benthamiana 16c plants were photographed under UV illumination at 30 days after biolistic inoculation with p35S-green fluorescent protein (GFP) and the infectious components Cotton leaf curl Multan virus (CLCuMV), Cotton leaf curl Multan betasatellite (CLCuMB), and Cotton leaf curl Multan alphasatellite (CLCuMA) in various combinations as detailed under the photographs. B, RNA blot hybridizations of 16c plants inoculated with the components of the cotton leaf curl disease complex probed for the presence of GFP mRNA and GFP small-interfering RNA (siRNA). A separate blot was probed for U6 RNA to act as a loading control. 
silencing; Baulcombe 2004; Baulcombe 1996). The genomes of RNA viruses, or the transcripts of DNA viruses, are recognized in a sequence-homology-dependent manner and are degraded in the cytoplasm of infected cells. The existence of virus-encoded silencing suppressors strongly suggests that RNAi acts as an adaptive defense against viruses (Ding et al. 2004; Roth et al. 2004). Viruses have acquired a variety of suppressors and some even encode multiple suppressors that interfere at different steps of the silencing pathway (Burgyan 2008; Voinnet 2005). The first such suppressor to be identified was the helper component protease (HC-Pro) of Tobacco etch virus (TEV) (Anandalakshmi et al. 1998; Brigneti et al. 1998; Kasschau and Carrington 1998; Llave et al. 2000).

Whitefly-transmitted leaf curl diseases of a number of plant species have been known since the early twentieth century (Muniyappa 1980). The symptoms of CLCuD consist of leaf
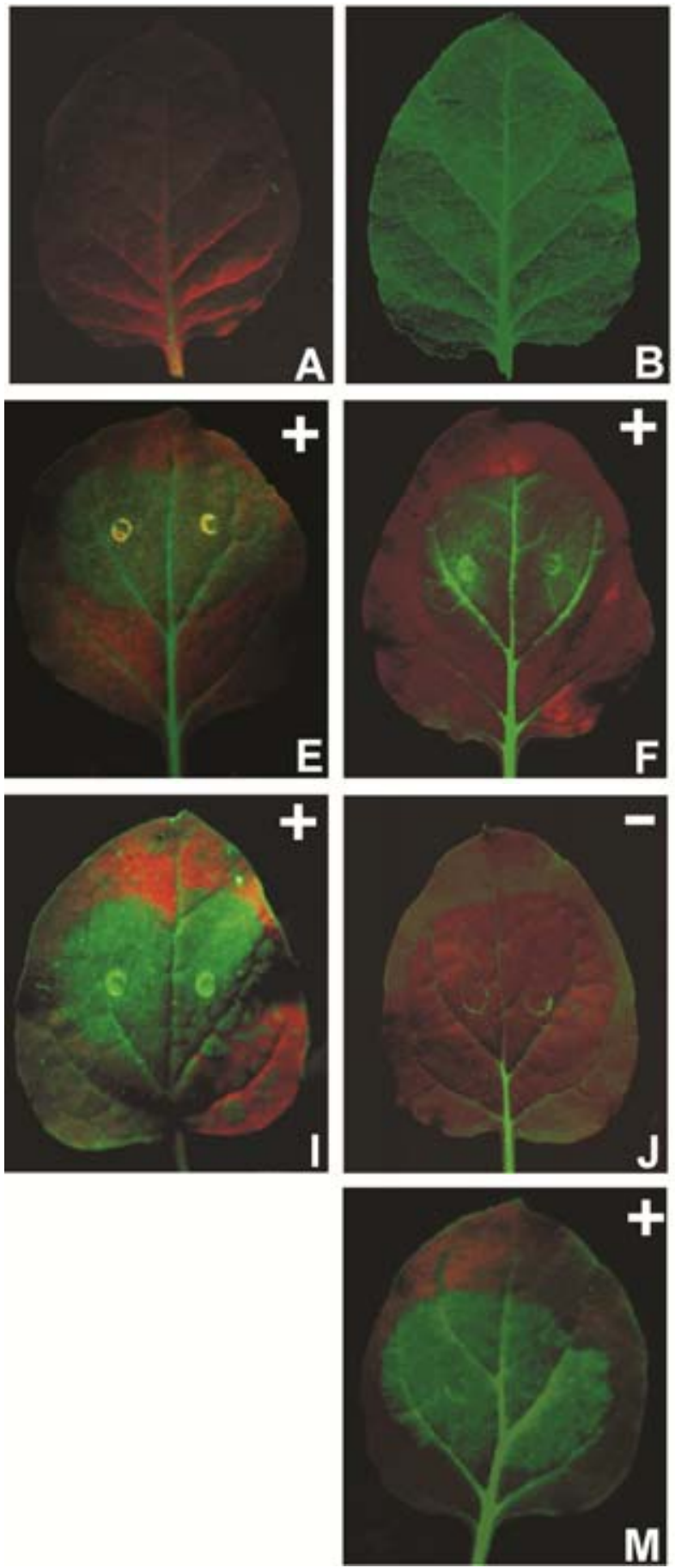
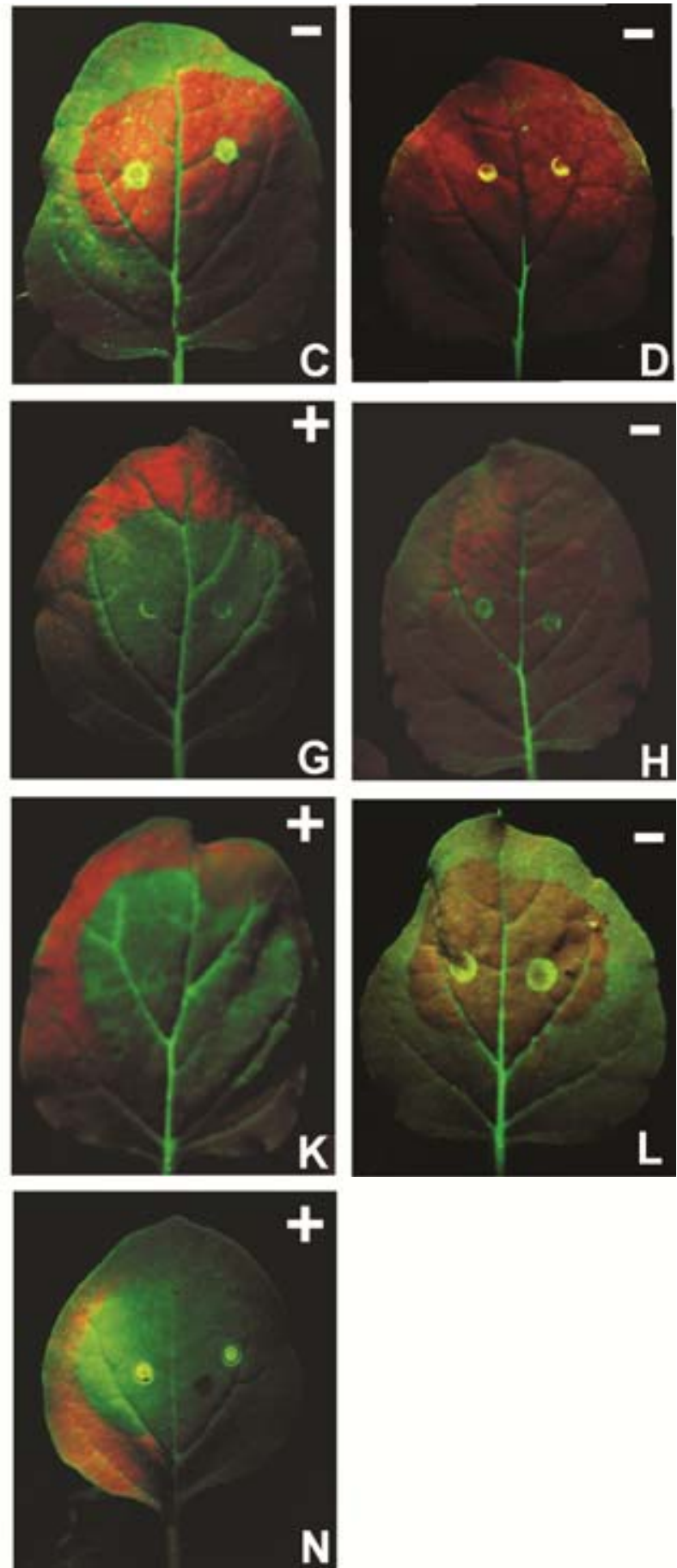

Fig. 3. RNA-silencing suppression activity of Cotton leaf curl Multan virus (CLCuMV)- or Cotton leaf curl Multan betasatellite (CLCuMB)-encoded genes in Nicotiana benthamiana 16c plants. Leaves from the following are shown: A, a nontransgenic $N$. benthamiana plant, B, a N. benthamiana line 16c plant, C, a $N$. benthamiana line 16c plant inoculated with the silencing construct (RNAi-GFP), D to N, $N$. benthamiana line 16c plants co-inoculated with RNAiGFP and either D, pGreen0029 or constructs for the expression of $\mathbf{E}$, the helper component protease of Tobacco etch virus, $\mathbf{F}$, the P19 protein of Cymbidium ringspot virus, $\mathbf{G}$, the coat protein of Turnip crinkle virus, $\mathbf{H}$, the replication-associated protein of CLCuMV, I, the C2 protein of CLCuMV, J, the replication enhancer protein of CLCuMV, $\mathbf{K}$, the C4 protein of CLCuMV, $\mathbf{L}$, the coat protein of CLCuMV, M, the V2 protein of CLCuMV, or $\mathbf{N}$, the $\beta C 1$ protein encoded by CLCuMB. Photographs were taken under UV illumination $72 \mathrm{~h}$ after inoculation. Suppression activity is indicated by "+", whereas a lack of suppression is indicated by "-". 
curling, vein swelling, and enations on the undersides of leaves that frequently differentiate into cup-shaped leaf-like structures (Briddon and Markham 2001). CLCuD was first recorded on cotton from Multan in 1967 (Hussain and Ali 1975). The disease remained of little importance until 1988, when it affected larger plantings of cotton and resulted in an epidemic in the 1990s in Pakistan, causing 30 to $40 \%$ yield losses with a total value of more than \$5 billion U.S. from 1993 to 1997. Following the introduction of resistant cultivars during the late 1990s, losses were reduced. However, the disease returned to prominence in 2001 and is now the most important factor limiting cotton productivity in Pakistan and northwestern India (Mansoor et al. 2003a and b).

The factors allowing a virus to successfully infect cotton are not fully understood. Plants being infected with multiple viruses and the propensity of begomoviruses to recombine often results in novel viruses with enhanced virulence. The beststudied example is the ongoing pandemic of cassava mosaic disease in Africa, for which a synergistic interaction between two distinct begomoviruses results in severe disease symptoms with no recovery from the disease (Vanitharani et al. 2004). The synergism is believed to result from the action of two suppressors of RNA silencing that act at different stages of the RNA silencing pathway and, thus, effectively overcome host defense.

Here, we have examined all proteins encoded by one of the CLCuD-associated begomoviruses, Cotton leaf curl Multan virus (CLCuMV), and CLCuMB for their gene silencing potential. We show that CLCuMV encodes three suppressors and CLCuMB an additional one. This profusion of suppressors suggests that RNAi-based host resistance is a major obstacle for the virus complex to overcome.

\section{RESULTS}

\section{Suppression of silencing by components of the cotton leaf curl Begomovirus complex.}

To assess the ability of the various components of the CLCuD-complex in suppression of gene silencing during a bona fide infection, the infectious components (viral and satel lite DNAs) were biolistically inoculated to Nicotiana bentha miana line $16 \mathrm{c}$ plants together with p35S-GFP, a construct ex pressing green fluorescent protein (GFP) designed to initiate silencing. $N$. benthamiana line 16c constitutively expresses a GFP transgene (Ruiz et al. 1998). Plants were then examined for silencing of GFP expression by visual detection of $g f p$, analysis of the levels of $g f p$ mRNA, and production of small-interfering (si)RNA specific to $g f p$ sequences. $N$. benthamiana $16 \mathrm{c}$ plants not inoculated with p35S-GFP appeared entirely green under UV illumination due to GFP expression (Fig. 1A, panel a). These plants contained relatively high levels of $g f p$ mRNA, with no evidence of siRNA derived from $g f p$ (Fig. 1B, lane 5). In contrast, 16c plants inoculated with only p35S-GFP showed near-complete GFP silencing, appearing almost en tirely red under UV illumination at 30 days post inoculation (dpi). Such plants contained only small amounts of gfp mRNA and relatively high levels of siRNA derived from $g f p$ (Fig. 1A, panel b and B, lane 4), indicative of silencing of the GFP trans gene.

Line 16c plants inoculated with p35S-GFP and CLCuMV exhibited the first mild symptoms of infection (characteristically mild downward leaf curling of the youngest, newly emerging leaves) (Briddon et al. 2000) at $21 \mathrm{dpi}$, with all plants that were ultimately to show symptoms being symptomatic by $30 \mathrm{dpi}$. In these plants, systemic silencing was delayed (patches of green fluorescence were still visible on the upper leaves) but, gradually, silencing proceeded to affect the entire plant (Fig. 1A, panel d). The levels of $g f p$ mRNA and siRNA in such plants were similar to those of plants inoculated with only p35S-GFP, with low mRNA and relatively high siRNA levels (Fig. 1B, lane 2). This indicated that the begomovirus alone was unable to overcome either local or systemic silencing but only delayed the onset of silencing.

Plants inoculated with p35S-GFP with both CLCuMV and the betasatellite developed symptoms typical of CLCuD, consisting of downward leaf curling, vein swelling, and small enations on the veins on the undersides of leaves (Briddon et al. 2001). Under UV illumination, the young parts of the plant that developed at or after the time of inoculation appeared entirely green, indicating complete suppression of silencing. Some of the older leaves, which were expanding at the time of inoculation, showed some evidence of silencing, but that was extremely delayed. The plants infected with virus and betasatellite contained higher levels of $g f p$ mRNA than that detected in the nonsilenced control, and lower levels of $g f p$ siRNA than was detected in either the silenced control or the plant only inoculated with CLCuMV (Fig. 1A and B, lane 1). This indicated that, during systemic infection, efficient silencing in planta required the betasatellite.

Additionally, 16c plants were inoculated with p35S-GFP, CLCuMV, the betasatellite, and the CLCuD-associated alphasatellite (Cotton leaf curl Multan alphasatellite [CLCuMA]). The phenotype of such plants was indistinguishable from plants inoculated with CLCuMV and CLCuMB with high $g f p$ mRNA and low $g f p$ siRNA levels (Fig. 1A, panel e, and B, lane $3)$. This indicated that the alphasatellite had no significant effect on either the severity of the disease or the outcome of silencing. However, when examined for the presence of siRNA complementary to the alphasatellite, such molecules were present (Fig. 2). This is the first time an alphasatellite has been shown to be the target of RNA-mediated silencing. Similarly, siRNAs against the virus and the betasatellite were detected in plants inoculated with these components, even in plants in which strong suppression of silencing was evident (plants inoculated with CLCuMV and the betasatellite). In fact, higher levels of siRNAs derived from the virus were detected in plants co-inoculated with the betasatellite than in plants inoculated with only CLCuMV (Fig. 2).

\section{Identification of suppressors of gene silencing encoded by CLCUMV and CLCuMB.}

Inoculation of 16c plants with RNAi-GFP led to silencing of the $g f p$ transgene (seen as an absence of green fluorescence and the appearance of red chlorophyll autofluorescence) in the infiltrated tissue $72 \mathrm{~h}$ after inoculation (Fig. 3C). Northern analysis showed a decrease in $g f p$ transcript and an increased accumulation of siRNA compared with control $N$. benthamiana $16 \mathrm{c}$ plants (Fig. 4A and B). Systemic spread of the silencing (red veins) was also observed in new leaves emerging above the site of inoculation at $8 \mathrm{dpi}$ and that further spread into younger leaves by 16 dpi. Co-inoculation of Agrobacterium cultures harboring the binary vector with no insert (pGreen0029) along with RNAiGFP resulted in silencing of GFP expression in the infiltrated patch after $72 \mathrm{~h}$. These results were compar able with the results with just RNAi-GFP (Fig. 3D). Northern analysis showed a decrease in $g f p$ transcript and an increased accumulation of siRNA compared with $16 \mathrm{c}$ plants (Fig. 4A and B).

Co-inoculation of the RNAi-GFP construct with constructs for the expression of HC-Pro, P19, and Turnip crinkle virus (TCV)-CP showed suppression of GFP silencing in the inoculated patch after $72 \mathrm{~h}$ (Fig. 3E, F, and G, respectively), as was evident from high levels of GFP fluorescence under UV illumination. Northern analysis showed an increased level of $g f p$ mRNA, with the greatest increase for TCV-CP (Fig. 4A). The accumulation of $g f p$ siRNA was reduced in all three cases (Fig. 
4B). The siRNA accumulation in presence of HC-Pro was slightly higher than that for P19 and TCV-CP (Fig. 4B).

The results for GFP fluorescence analysis upon co-inoculation of 35S-driven genes encoded by CLCuMV or CLCuMB with RNAi-GFP are shown in Figure 3. A decrease in GFP fluorescence was observed after $72 \mathrm{~h}$ for 35S-Rep, 35S-REn, and 35S-CP (Fig. 3H, J, and L, respectively). Northern analysis showed a decrease in $g f p$ transcript levels and an increased accumulation in $g f p$ siRNA levels compared with noninoculated 16c plants (Fig. 4A and B). In contrast, 35S-C2-, 35S-C4-, $35 \mathrm{~S}-\mathrm{V} 2-$, and $35 \mathrm{~S}-\beta \mathrm{C} 1$-inoculated plants showed an enhanced level of GFP fluorescence under UV illumination compared with the noninoculated control (Fig. 4I, K, M, and N, respectively). Northern analysis of these plants showed an increase in the level of $g f p$ mRNA. The greatest increase was detected for 35S-V2 followed by 35S-C4 (Fig. 4A). Analysis of siRNA levels showed a decrease in $g f p$-derived siRNAs in these plants with slightly higher levels in plants inoculated with $35 \mathrm{~S}-\mathrm{C} 2$ and $35 \mathrm{~S}-\beta \mathrm{C} 1$ than in the plants inoculated with $35 \mathrm{~S}-\mathrm{V} 2$ or 35S-C4 (Fig. 4B). Northern blotting (Fig. 4) also revealed that TCV-CP was the strongest suppressor of gene silencing among the tested known suppressors in this study and, likewise, V2 was the strongest suppressor of gene silencing encoded by the CLCUMV/CLCuMB complex, followed by $\mathrm{C} 4, \mathrm{C} 2$, and $\beta \mathrm{C} 1$.

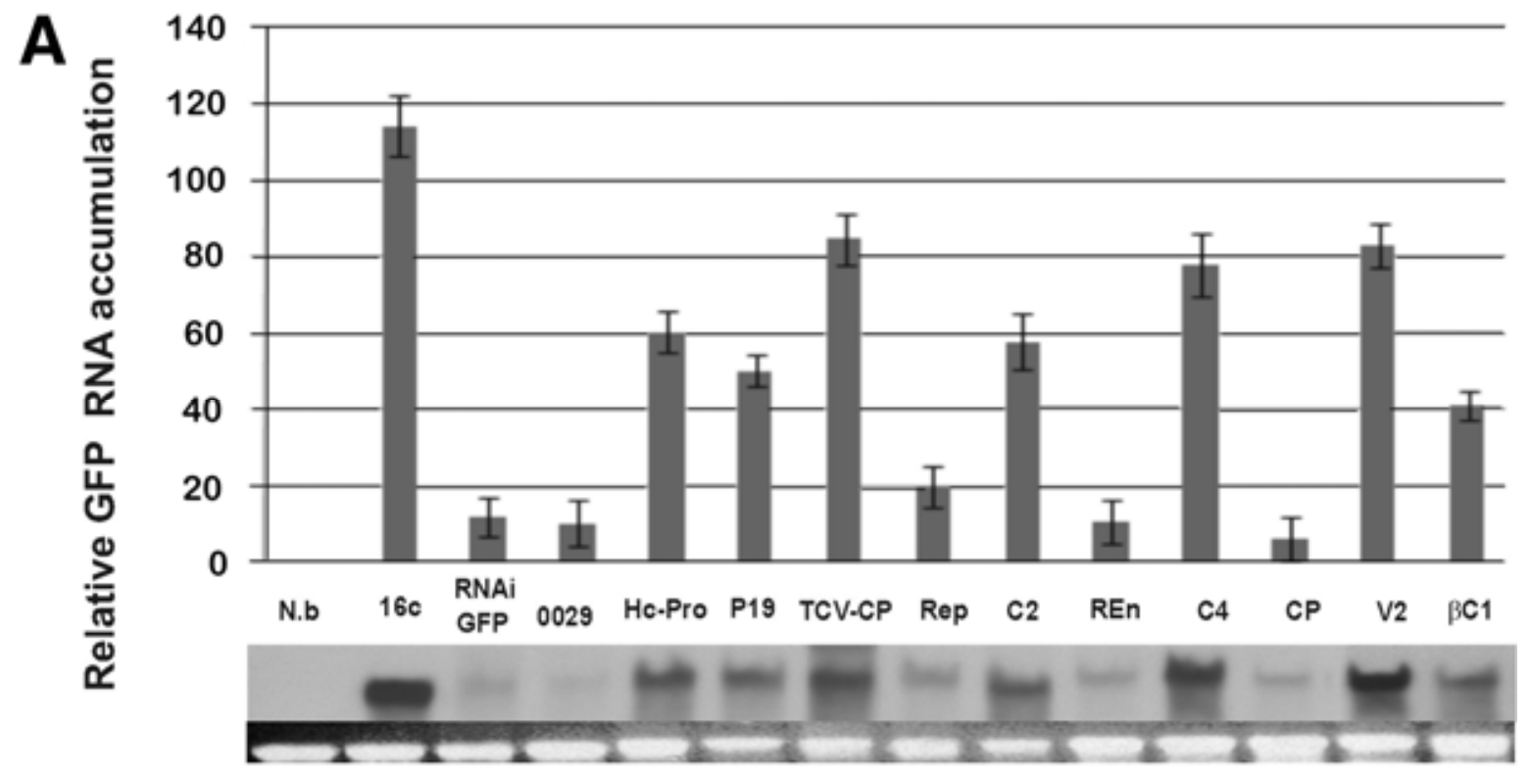

B

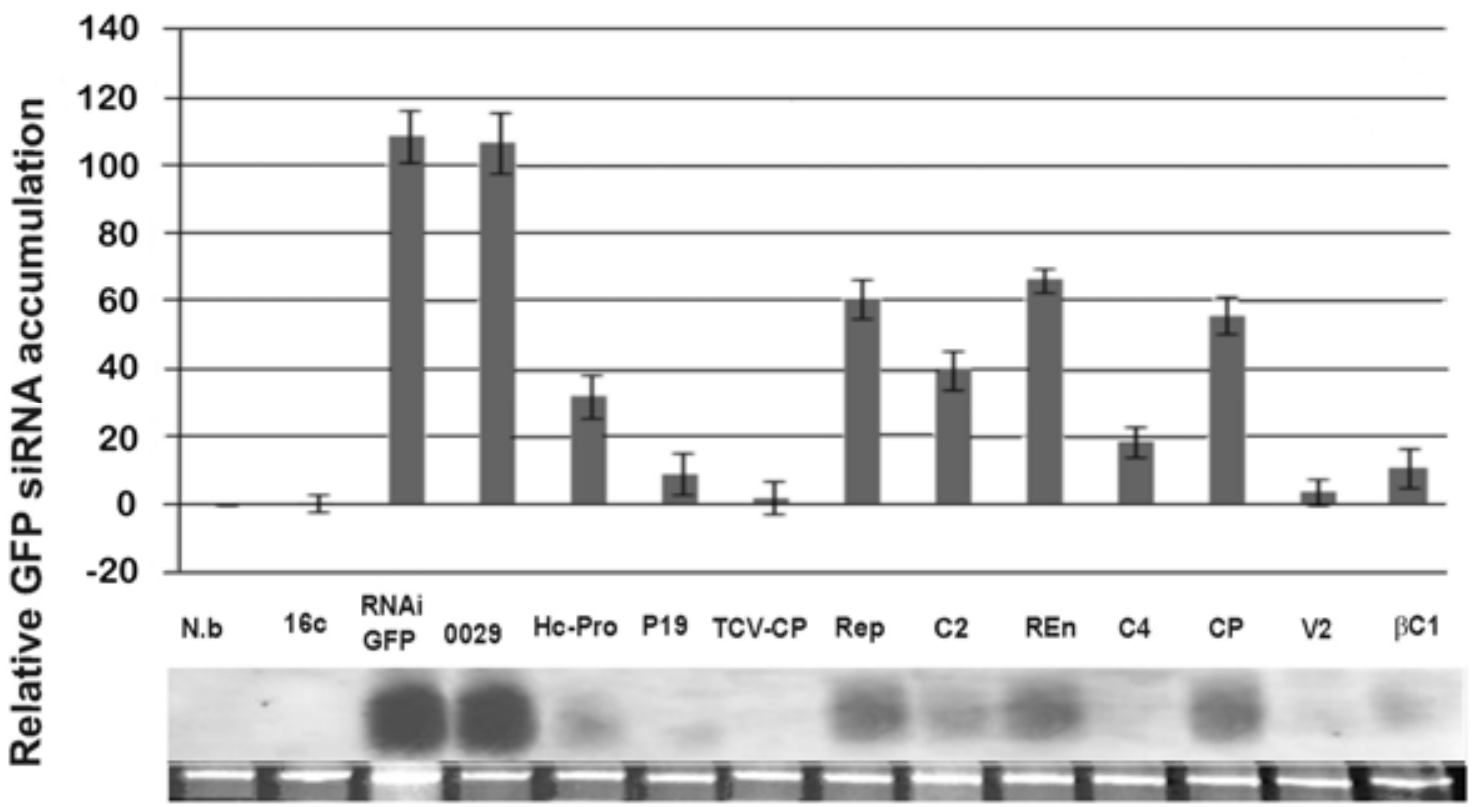

Fig. 4. Northern blot analysis for A, green fluorescent protein (GFP) mRNA and B, small-interfering RNA. RNA samples were extracted from the leaves of wild-type Nicotiana benthamiana $(\mathrm{Nb})$ or $N$. benthamiana line $16 \mathrm{c}(16 \mathrm{c})$ plants. The remaining RNA samples were extracted from the infiltrated tissues of $N$. benthamiana line 16c plants inoculated with Agrobacterium cultures harboring a construct to induce silencing RNAi-GFP, the binary vector pGreen0029, or co-inoculated with RNAi-GFP and constructs for the expression of Cotton leaf curl Multan virus- or Cotton leaf curl Multan betasatellite-encoded genes. Total RNA was isolated from a pool of infiltrated tissues obtained from three plants for each sample. The experiment was conducted three times and the results shown are the mean with standard deviation. Values shown are normalized against the mRNA loading (shown in each case below the Northern blot) and the value for $N$. benthamiana was in each case set at zero. The proteins expressed were the helper component protease of Tobacco etch virus (HC-Pro), the P19 protein of Cymbidium ringspot virus (P19), the coat protein of Turnip crinkle virus (TCP-CP), the $\beta \mathrm{C} 1$ protein encoded by Cotton leaf curl Multan betasatellite $(\beta C 1)$ as well as the replication-associated protein (Rep), $\mathrm{C} 2$ protein $(\mathrm{C} 2)$, replication enhancer protein (REn), $\mathrm{C} 4$ protein $(\mathrm{C} 4)$, coat protein $(\mathrm{CP})$, and $\mathrm{V} 2$ protein (V2) encoded by Cotton leaf curl Multan virus. 
The quantitative real-time polymerase chain reaction (qPCR) analysis of $g f p$ expression had a high efficiency (98.9\%), and melt curve data (not presented) showed a single peak, indica tive of the specific amplification of a single $g f p$ product. With reference to the calculated standard curve for $g f p$ mRNA, $16 \mathrm{c}$ plants were shown to contain $g f p$ mRNA at approximately 11 $\mathrm{pg} / \mu \mathrm{g}$ of total RNA (Fig. 5A). Plants co-in oculated with RNAi-GFP and the vector control, 35S-Rep, or 35S-REn showed no detectable $g f p$. mRNA at $4,5.5$, and $9 \mathrm{pg} / \mu \mathrm{g}$ of total RNA was calculated for plants co-inoculated with RNAi-GFP and 35S-P19, 35S-HC-Pro, or 35S-TCV-CP respectively (Fig. 5A). $g f p$ mRNA at $3.5,4.75,8$, and $4 \mathrm{pg} / \mu \mathrm{g}$ of total RNA was calculated for plants co-infiltrated with RNAi-GFP and 35SC2, 35S-C4, 35S-V2, or 35S- $\beta \mathrm{C} 1$, respec tively (Fig. 5A).

The qPCR analysis confirmed the results obtained with Northern blotting experiments, showing that TCV-CP led to the greatest increase in $g f p$ transcripts, followed by HC-Pro and P19 (Figs. 4 and 5). Similarly, the greatest increase of $g f p$ transcripts for plants inoculated with CLCuMV/CLCuMB genes was for $\mathrm{V} 2$ gene followed by $\mathrm{C} 4, \mathrm{C} 2$, and $\beta \mathrm{C} 1$ (Fig. 4).

\section{Suppressors encoded}

by CLCuMV and associated satellite bind RNA.

To assess the ability of suppressors encoded by CLCuMV and its satellite to bind RNA, in vitro binding assays with both long and short double-stranded (ds) and ssRNAs were conducted. Unfortunately, it was not possible to express CLCuMV $\mathrm{C} 2$ using the pEXP5-TN/TOPO system. It is likely that the CLCuMV C2 protein is toxic to Escherichia coli. This toxicity of Begomovirus TrAP/C2 encoded by some begomoviruses has been noted previously, leading to an inability to successfully regenerate transgenic plants (Hong et al. 1997; Rajeswaran et al. 2007).

These studies showed that P19 binds both short and long RNA with a preference for the ds form, consistent with the

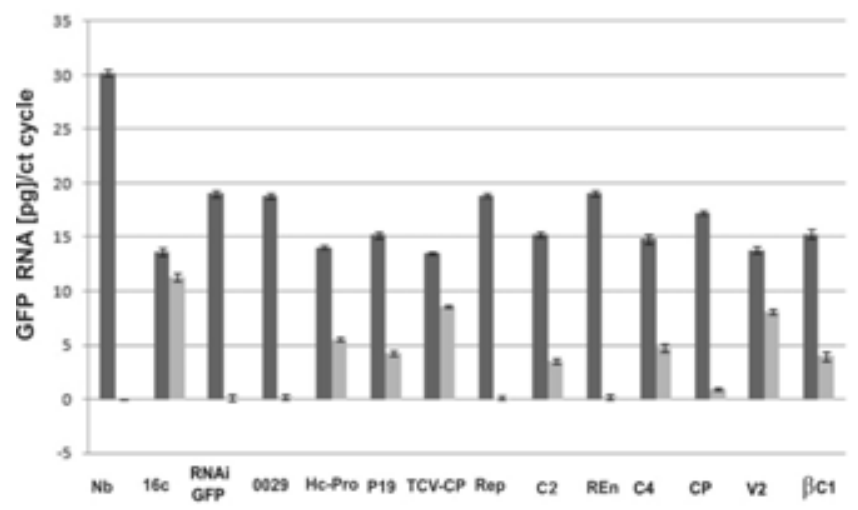

Fig. 5. Quantitative real-time polymerase chain reaction analysis of green fluorescent protein (GFP) expression from Nicotiana benthamiana 16c leaves infiltrated with Agrobacterium cultures harboring a construct to induce silencing (RNAi-GFP), the binary vector pGreen0029, or co-inoculated with RNAi GFP and constructs for the expression of Cotton leaf curl Multan virus- or Cotton leaf curl Multan betasatellite-encoded genes. Total RNA was isolated from a pool of infiltrated tissues obtained from three plants for each combination. Bar graph showing the amplification of GFP RNA along with threshold cycles $(\mathrm{Ct})$ in different treatments as mentioned. Dark gray bars represent the $\mathrm{Ct}$ cycle and light gray bars represent the concentration in picograms. The experiment was conducted three times and the results shown are the means with standard deviation. The proteins expressed were the helper component protease of Tobacco etch virus (HCPro), the P19 protein of Cymbidium ringspot virus (P19), the coat protein of Turnip crinkle virus (TCP-CP), the $\beta \mathrm{C} 1$ protein encoded by Cotton leaf curl Multan betasatellite $(\beta C 1)$ as well as the replication-associated protein (Rep), C2 protein (C2), replication enhancer protein (REn), C4 protein $(\mathrm{C} 4)$, coat protein $(\mathrm{CP})$ and V2 protein (V2) encoded by Cotton leaf curl Multan virus. generally accepted view that this protein suppresses silencing by binding ds siRNA (Lakatos et al. 2004; Sharma and Ikegami, 2008). Of the proteins examined here, P19 had the strongest affinity for all RNA forms. All three of the begomovirus-associated proteins which were successfully expressed and purified using the $E$. coli system $(\mathrm{C} 4, \mathrm{~V} 2$, and $\beta \mathrm{C} 1)$ interacted with RNA, binding to long RNAs with a preference for the ds form (Fig. 6A). Among these, the strongest binding of long dsRNA was by $\mathrm{C} 4$, whereas the $\beta C 1$ protein showed the weakest binding.

The binding assays with short RNA indicated that the V2 protein does not interact under the conditions of the assays conducted here (Fig. 6B). In contrast, C4 showed a strong binding of short RNA, with a preference for the ds form. $\beta \mathrm{C} 1$ also showed short RNA binding activity but far weaker than that of $\mathrm{C} 4$ and with a preference for the ss form.

\section{DISCUSSION}

Silencing is a mechanism of plant defense against viruses and, consequently, viruses have evolved a counter-defense strategy involving proteins capable of suppressing silencing. For
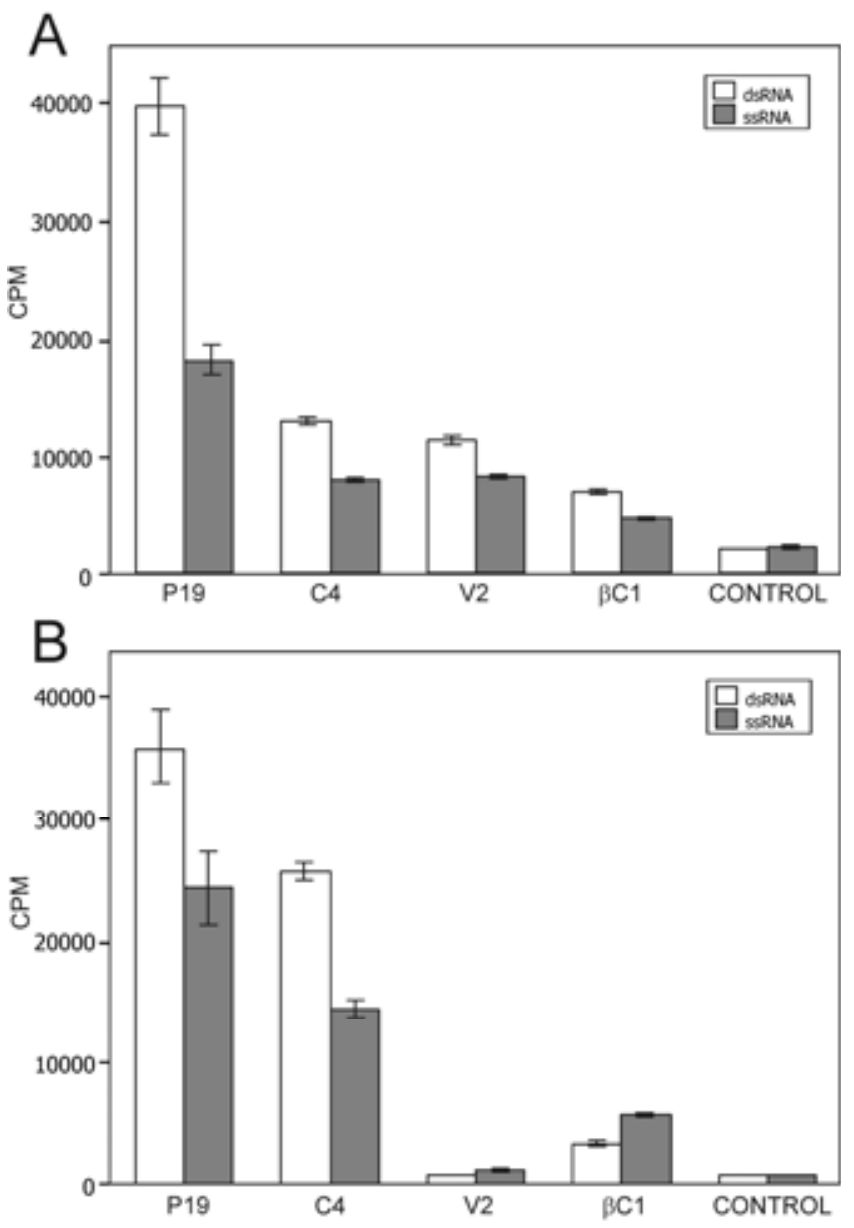

Fig. 6. Virus and satellite-encoded suppressors of silencing bind RNA. In vitro binding of proteins to radioactively-labeled single-stranded and double stranded A, long RNA and B, short RNA. Figures on the left of each plot are counts per minute (CPM) of labeled RNA retained on membranes. Results are the means of three independent experiments with standard deviations for each value. The binding of RNAs to Escherichia coli-expressed Cymbidium ringspot virus $\mathrm{P} 19$ and Cotton leaf curl Multan virus $\mathrm{C} 4$, and V2 proteins, as well as the betasatellite-encoded $\beta \mathrm{C} 1$ protein immobilized on nitrocellulose membranes was assessed. The control consisted of a membrane with no bound protein. 
plant-infecting viruses, numerous distinct suppressors have been identified ( $\mathrm{Li}$ and Ding 2006) and virtually all classes of viruses, including geminiviruses (Bisaro 2006; Sharma and Ikegami 2008), have been shown to encode at least one suppressor, highlighting the importance of silencing in host defense against viruses. Earlier studies have assessed only single or, at most, four gene products (coming from one or more than one virus) for suppression of gene silencing, with no comparison of the relative strengths of suppression (Vanitharani et al. 2004). Thus, the literature contains only fragmentary data on viral suppressors of gene silencing, making it difficult to compare the results obtained here with well-known viral suppressors of gene silencing such as HC-Pro, P19, and TCV-CP. Surprisingly, the results show that the CLCuD complex (that is, CLCuMV with CLCuMB) encodes four gene products with suppressor activity. The greatest number of suppressors reported so far are from one virus. Previously, Citrus tristeza virus (CTV) was shown to encode three suppressors ( $\mathrm{Lu}$ et al. 2004). The gene products of begomoviruses not analyzed previously, or at least not reported to have been analyzed previously (the Rep, CP, and REn) are shown here for the first time to not have suppressor activity, at least under the conditions of the analyses conducted here.

Several geminivirus-encoded proteins, as well as $\beta C 1$ encoded by begomovirus-associated betasatellites, have previously been shown to have a suppressor of gene silencing activity (Bisaro 2006). The AV2 protein of bipartite begomoviruses (which is a homolog of the V2 protein of monopartite begomoviruses and is not encoded by the genomes of New World begomoviruses) has been shown to possibly play a role in virus movement in plants; viruses with mutated AV2 genes induce mild symptoms and accumulated greatly reduced levels of viral DNA in plants (Bull et al. 2007; Padidam et al. 1996). In contrast, the V2 of monopartite begomoviruses was found to be essential for infectivity (Wartig et al. 1997) or to yield a phenotype very similar to the bipartite begomoviruses when mutated (attenuated symptoms and reduced viral DNA levels; Rigden et al. 1993). The V2 protein of Tomato yellow leaf curl virus (TYLCV) was shown to target silencing subsequent to the Dicer-mediated cleavage of dsRNA (Zrachya et al. 2007) and to bind siRNA (Fukunuga and Doudna 2009). This contrasts with our results that suggest that CLCuMV V2 may interfere with silencing by sequestering long dsRNA, thus preventing Dicer-mediated cleavage and siRNA production. It is also interesting to note that, for TYLCV, the V2 was suggested to be the only suppressor encoded by the virus, clearly contrasting with the results obtained here, which suggest the V2 is the strongest of multiple suppressors. Zrachya and associates (2007) also showed that the AV2 protein of Watermelon chlorotic stunt virus (a bipartite Begomovirus sp.) had no detectable suppressor activity, suggesting that bipartite and monopartite begomoviruses may differ in their utilization of this gene product as a suppressor.

Previous studies that have analyzed the TrAP/C2 of begomoviruses and its homolog (C2) in curtoviruses have concluded that they have suppressor activity, although they differed in the levels of activity (Bisaro 2006). Thus, the CLCuMV C2 is not an exception to this rule. The TrAP of bipartite and some monopartite begomoviruses is a multifunctional protein that is required for transactivation of the late, virion-sense-encoded genes (Dry et al. 2000; Hussain et al. 2007; Rajeswaran et al. 2007; Sunter and Bisaro 1992). For CLCuMV, the C2 homolog of TrAP appears not to transactivate virion-sense genes (L. Amrao, unpublished results). Importantly, TrAP also appears to modulate host encoded genes. The African cassava mosaic virus (ACMV) TrAP did not show any ability to bind siRNA or miRNA, ruling out the possibility that they might act by a mechanism similar to P19 (Chellappan et al. 2005; Wang et al. 2005). Transcriptional profiling in Arabidopsis protoplasts following transient expression of ACMV and Mung bean yellow mosaic virus TrAP showed that these proteins induced the expression of approximately 30 genes, including Werner exonuclease-like 1 (WEL1). Subsequent analysis of WEL1 indicated that it is capable of suppressing RNA silencing in $N$. benthamiana line 16c (Trinks et al. 2005). These remarkable findings suggest that TrAP suppresses silencing indirectly by activating the expression of a cellular protein that may function as an endogenous negative regulator of the system. The mechanism by which suppression occurs is not yet clear. Because genes encoding other WEL1 have been implicated as positive regulators of silencing, it is possible that WEL1 might exert a dominant negative effect (Trinks et al. 2005). The study presented here did not shed light on the mode of action of CLCuMV C2 with respect to suppression; therefore, further studies will be required to answer this question.

The precise function of the begomovirus-encoded (A)C4 product remains unclear. For monopartite begomoviruses, the C4 can be an important symptom determinant (Rigden et al. 1993) and has been implicated in virus cell-to-cell movement (Rojas et al. 2001). For the bipartite begomoviruses, the function of AC4 appears redundant, although van Wezel and associates (2002) have provided evidence to suggest that the protein may counter a hypersensitive response triggered by Rep. The AC4 protein of ACMV has been shown to act as a suppressor of RNA silencing by binding ss but not ds siRNAs (Chellappan et al. 2005). The same study also showed that the AC4 of East African cassava mosaic Cameroon virus (EACMCV) had no such small RNA binding activity. For CLCuMV, it is shown here that $\mathrm{C} 4$ binds both long and short RNAs, with a preference for the dsRNA form in each case. Also, for each assay (ds and ssRNA binding), the $\mathrm{C} 4$ was shown to have the highest affinity of the proteins examined in each case. These findings differ from the findings of Chellappan and associates (2005) for ACMV, which suggested that AC4 might interfere with silencing downstream of the ds siRNA duplex unwinding process prior to incorporation into RNAinduced silencing complex (RISC). The study with CLCuMV suggests that its $\mathrm{C} 4$ protein may act both to sequester siRNA from incorporation into RISC, prior to duplex unwinding, as well as to sequester long dsRNA from Dicer-mediated cleavage.

The $\beta C 1$ proteins encoded by begomovirus-associated betasatellites have been shown to have suppressor of RNA silencing activity (Cui et al. 2005; Gopal et al. 2007; Kon et al. 2007). The results presented here concur with these previous observations, showing, for the first time, gene silencing activity for the CLCuD-associated satellite, CLCuMB. betasatellites encode only a single product ( $\beta C 1$ ) (Saeed et al. 2005; Saunders et al. 2004) ) which, in addition to being a suppressor, is a pathogenicity determinant, possibly binds DNA, and may be involved in virus movement in plants (Briddon et al. 2001; Gopal et al. 2007; Kon et al. 2007; Saeed et al. 2005; Saunders et al. 2000, 2004). CLCuMB $\beta C 1$ binds both long and short RNA, with a preference for long RNA and the ds form, suggesting that, in common with $\mathrm{C} 4, \beta \mathrm{C} 1$ may act both to interfere with long dsRNA cleavage by Dicer and sequester siRNA from incorporation into RISC.

ACMV and EACMCV are two bipartite begomoviruses that are responsible for an epidemic of severe cassava mosaic disease (CMD) in Cameroon (Fondong et al. 1998). The interaction between the viruses is synergistic, with cassava plants infected with both viruses showing more severe symptoms than plants infected with either virus individually (Fondong et al. 2000). The basis for this synergism was shown to be cooperative, with each virus providing a distinct suppressor of silencing able to enhance the accumulation of the other virus; spe- 
cifically, the AC4 of ACMV and the TrAP of EACMCV (Vanitharani et al. 2004). The authors concluded that the ACMV-encoded suppressor provides strong suppression at the early stages of infection and that symptoms of ACMV infection typically appear earlier than those of EACMCV but that this is transient and plants then rapidly recover from infection (a well-known phenomenon for ACMV; Gibson and Otim-Nape 1997). In contrast, the EACMCV suppressor was slower acting but persists until plants senesce; typically, plants infected by EACMCV do not recover from infection. The situation with the CLCuD complex is, in many respects, similar to the ACMV and EACMCV synergism. CLCuMV by itself is infectious to both $N$. benthamiana and Gossypium hirsutum but yields plants with mild symptoms (for $N$. benthamiana) or no discernable symptoms (for G. hirsutum) (Briddon et al. 2001). The CLCuD complex can be seen as a synergistic interaction in which CLCuMB provides efficient access to cotton for the begomoviruses with which it is associated (here, CLCuMV), which the viruses cannot achieve effectively in the absence of the betasatellite. As with the ACMV-EACMCV synergism, it is possible that the basis for the synergism is the provision by each component of the synergistic interaction of a distinct suppressor.

Quantitative RNA analysis showed that V2 is the strongest suppressor of gene silencing among genes encoded by the $\mathrm{CLCuMV/CLCuMB}$ complex, followed by $\mathrm{C} 4, \mathrm{C} 2$, and $\beta \mathrm{C} 1$. By no means should the relative strength of the suppressor, as determined by this study, be used as an indication of the importance of a particular gene. These results are from the constitutive expression of each gene and do not represent the level of expression and, thus, total suppressor activity of the gene that occurs during a bona fide virus infection. During virus infection, gene expression is tightly regulated, both spatially and temporally, according to the requirements of the virus at the particular stage of infection. For example, although TrAP/C2 is highly conserved between all begomoviruses and, thus, might be considered essential, recently, a begomovirus associated with $\mathrm{CLCuD}$ (CLCuBuV, the only begomovirus presently found causing CLCuD in the field in Pakistan) lacks an intact $c 2$ (Amrao et al. 2010) and, thus, appears able to infect cotton without the suppressor activity it provides, despite the fact that, at least for CLCuMV, it is the secondstrongest suppressor encoded. A further complication is that all these suppressor analyses are conducted in the model host $N$. benthamiana and, thus, the activities of the protein may differ qualitatively or quantitatively in the natural host of the virus. Clearly, further studies, preferably in the natural host, are required to more accurately define the requirement for and relative contribution of each suppressor.

The precise advantages derived by begomovirus-betasatellite complexes from the presence of alphasatellites are unclear. The widespread, although not universal, presence of alphasatellites in begomovirus-betasatellite infections suggests that some selective advantage must be derived from this association. It is noteworthy that the most recent epidemic of CLCuD was not associated with alphasatellites, reinforcing the idea that alphasatellite functions are dispensable. Nevertheless, recently, the Reps of two alphasatellites have been shown to have suppressor of gene silencing activity, suggesting that these components are involved in overcoming RNA-mediated host defense (Nawaz-ul-Rehman et al. 2010). However, the very slight reduction in virus DNA levels seen experimentally in plants in the presence of alphasatellites compared with infections without these molecules has led to the suggestion that their presence reduces the severity of infection, increasing the likelihood for onward transmission of the complex. Most recently, this has been shown for a very unusual alphasatellite originating from Oman which caused significant symptom amelioration (Idris et al. 2011). A symptom amelioration effect would seem incompatible with a suppressor of gene silencing activity, which one would expect to increase virus-induced symptoms due to increased virus levels. One hypothesis, put forward when alphasatellites were first identified, suggests that alphasatellites achieve the downregulation of viral replication (symptom amelioration) by "mopping-up" cellular resources required for replication (Briddon et al. 2004). Our findings here possibly support an alternative hypothesis. alphasatellites may act to dilute the host response to the other components (begomovirus and betasatellite) by mopping-up the host silencing machinery (Dicers, RISC, and so on) in a futile defense against a nonessential molecule. The small decrease in virus levels seen in plants could be a side effect of the presence of the alphasatellite, a decrease the virus complex is able to tolerate in exchange for the benefits of a reduced host defense response. However, if alphasatellites act to deflect host defense, one might expect larger amounts of siRNAs complementary to the alphasatellite than to the virus. The fact that there are not might argue against this being the case. Further experiments will need to be conducted to test the validity of this hypothesis.

It is becoming evident that even quite similar begomoviruses have evolved quite distinct strategies with respect to overcoming the host-mediated defense based on the recognition of foreign nucleic acid sequences. These range from a single suppressor of silencing in the case of TYLCV (Zrachya et al. 2007), through having two suppressors that differ in their potency (Fondong et al. 1998), to the results described here: four different suppressors. This is the first report of a virus apparently requiring four suppressors to establish infections in plants in the field (CLCuMV has an absolute requirement for CLCuMB to infect cotton). These findings may also be of significance to efforts to generate resistance to CLCuD based upon RNAi. Multiple suppressors, acting at distinct stages in the RNAi pathway, may possibly compromise any resistance based upon siRNA production. A further detailed study is required to understand the role and activity of each suppressor encoded by the CLCuMV/CLCuMB complex. A further question that needs to be addressed is whether the CLCuD complex is typical of betasatellite-associating begomoviruses and, particularly, whether the begomovirus-betasatellite complexes that do not infect malvaceous hosts similarly utilize four suppressors.

\section{MATERIALS AND METHODS}

\section{Biolistic inoculation of virus and satellites.}

GFP transgenic $N$. benthamiana plants (line 16c) were grown from seed at $26^{\circ} \mathrm{C}$ with a 16 -h day and 8 -h night. At 4 to 5 weeks after germination, the plants were inoculated with CLCuMV and associated satellite molecules along with p35SGFP, a pUC18 plasmid containing mGFP-ER with a $35 \mathrm{~S}$ pro moter and Nos terminator (Haseloff et al. 1997). Biolistic inoculations were conducted using a PDS-1000/He biolistic particle delivery system (Bio-Rad, Munich, Hercules, CA, U.S.A.). Gold particles $(750 \mu \mathrm{g} / \mu \mathrm{m})$ were coated with a plas mid mixture $(0.5$ $\mu \mathrm{g}$ of each) of the infectious clones of CLCuMV (CLCuMVFai[PK:Fai2]; database accession num ber AJ496287) (Mansoor et al. 2003a and b), CLCuMB-(PK:Fai1:96) (accession number AJ298903) (Briddon et al. 2003), and the associated alphasatellite (CLCuMA; accession number AJ132345) (Mansoor et al. 1999) and delivered at $1,100 \mathrm{psi}$, following the manufacturer's recommendations. The plants were kept in the insect-free chambers at $26^{\circ} \mathrm{C}$ with a regime of $16 \mathrm{~h}$ of day and $8 \mathrm{~h}$ of night. The youngest ex panding leaves of infected plants were harvested 30 dpi for RNA extraction. 
Production of gene expression constructs.

Genes for expression were obtained from CLCuMVFai[PK:Fai2] and CLCuMB-[PK:Fai1:96]. Genes encoding Rep (rep), C2 (c2), REn (ren), the C4 protein ( $c 4)$, the $\mathrm{CP}(c p)$, and the V2 protein $(v 2)$ of CLCuMV and $\beta C 1(\beta c 1)$ were amplified by PCR using Taq polymerase (MBI Fermantas) and specific primers with appropriate restriction sites (Supplementary Table 1). PCR products were cloned in pJIT163 (Guerineau et al. 1992), using restriction endonucleases SalI and either HindIII or SmaI and sequenced to ensure the fidelity of the constructs Then, for each gene, the whole expression cassette was transferred from pJIT163 into the binary vector pGreen0029 (Hellens et al. 2000) using restriction endonucleases SacI and XhoI. The 35S-driven HC-Pro (Brigneti et al. 1998), P19 (Voinnet et al. 2003), and TCV-CP (Thomas et al. 2003) were used as positive controls in this study. RNAi GFP DNA in sense orientation corresponding to the first $200 \mathrm{bp}$ of $g f p$ separated by an intron and the same DNA sequence in antisense orientation (Haseloff et al. 1997) in pGreen0029 was used a silencing construct. The gene fragment was first cloned in the RNAi vector pFGC5941 (Kerschen et al. 2004) and, subsequently, the expression cassette was transferred into pGreen0029 at EcoRI and HindIII restriction sites to yield RNAi-GFP.

\section{Inoculation of plants.}

After transformation of Agrobacterium tumefaciens GV3101 cells with pGreen0029 constructs, cells were grown for $48 \mathrm{~h}$ on Luria-Bertani (LB) agar containing the appropriate antibiotics. A single colony was picked and was grown in LB broth containing appropriate antibiotics to an optical density at 600 $\mathrm{nm}$ of 0.6. After centrifugation, cells were resuspended in 10 $\mathrm{mM} \mathrm{MgCl} 2$ and $150 \mu \mathrm{M}$ acetosyringone and stored at room temperature for 2 to $3 \mathrm{~h}$. Young, fully expanded leaves were infiltrated with a mixture of Agrobacterium cultures containing the constructs by gently appressing a 5-ml syringe to the abaxial surface of $N$. benthamiana line 16c leaves and depressing the plunger until a water-soaked appearance was achieved. Another silencing construct, p35S-GFP, a pUC18 plasmid containing mGFP-ER with a $35 \mathrm{~S}$ promoter and Nos terminator (Haseloff et al. 1997), was also used for silencing in the same way. Three leaves of approximately equal size on a single plant were infiltrated with RNAi GFP either alone, with empty vector, or with one of six constructs to be tested. All inoculations were repeated a minimum of three time in independent experiments.

\section{Analysis of GFP expression.}

Total RNA was extracted from infected plant material and northern blot analyses were conducted as described previously (Amin et al. 2011). Blots were hybridized with digoxigenin (DIG)-labeled probes specific to GFP gene synthesized using a DIG PCR labeling kit (Roche, Basel, Switzerland). Membranes were washed three times using $2 \times \mathrm{SSC}(1 \times \mathrm{SSC}$ is $0.15 \mathrm{M}$ $\mathrm{NaCl}$ plus $0.015 \mathrm{M}$ sodium citrate) and $0.1 \%$ (wt/vol) sodium dodecyl sulfate (SDS) and exposed to X-ray film after treatment with CDP-Star (Roche) according to the manufacturer's instructions.

Visual detection of GFP fluorescence in the inoculated patch of the plants was performed using a $100-\mathrm{W}$ handheld longwave ultraviolet lamp (BLAK-RAY Model B100 U.S.A., Upland, CA, U.S.A.) and pictures were taken under UV illumination using a high-resolution digital camera with a yellow filter.

\section{Analysis of siRNA accumulation.}

Samples of $30 \mu \mathrm{g}$ of total RNA diluted with loading dye were heated at $95^{\circ} \mathrm{C}$ for 2 min and loaded on $15 \%$ polyacryla- mide gels (19:1 ratio of acrylamide to bis-acrylamide, $8 \mathrm{M}$ urea). The gels were run at 150 to $250 \mathrm{~V}$ for $3 \mathrm{~h}$ and then the RNA was transferred to Hybond $\mathrm{N}+$ membranes by using a semi-dry electroblotting apparatus (Bio-Rad) in $1 \times$ Tris-borate EDTA buffer at $10 \mathrm{~V}$ for $2 \mathrm{~h}$. Hybridization was performed at $42^{\circ} \mathrm{C}$ for 14 to $24 \mathrm{~h}$ in DIG Easy Hyb buffer using a hydrolyzed in vitro transcribed GFP probe. A GFP probe was prepared by first cloning the GFP V gene in pTZ57R/T (Fermentas, Vilnius, Lithuania). In vitro transcription was performed using a DIG in vitro transcription kit (Roche) after linearizing the GFP clone with EcoRI. DIG-labeled transcripts were hydrolyzed using $1 \times$ alkaline lysis buffer $(50 \mathrm{mM}$ sodium carbonate buffer [pH 9.2], $1 \mathrm{mM}$ EDTA) and heating at $95^{\circ} \mathrm{C}$. Following hybridization, blots were washed three times in $2 \times \mathrm{SSC}$ and $0.1 \%$ (wt/vol) SDS and processed according to the manufacturer's instructions. Detection of siRNA accumulation using radioactive probes was conducted as described previously (Akbergenov et al. 2006).

\section{Real-time PCR quantification of suppression activity.}

Complementary DNA (cDNA) was synthesized from DNase I-digested total RNA ( $2 \mu \mathrm{g})$ from each control and tested constructs using the Platinum quantitative reverse-transcription PCR thermoscript one-step system (Invitrogen Life Technologies, Carlsbad, CA, U.S.A.) as described by the manufacturer. Sybergreen-based real-time qPCR was conducted on cDNA to quantify $g f p$ mRNA expression. Primers GFP-F1 (5'-CCAGAT CATATGAAGCGGCACGAC-3') and GFP-R1 (5'-ATCCTGT TGACGAGGGTGTCACC- $3^{\prime}$ ) were used to amplify an approximately $120-\mathrm{bp}$ fragment of $g f p$. For an absolute quantification of $g f p$ mRNA, a standard curve was obtained by using a serial dilution of a plasmid containing the full-length $g f p$ gene. The amount of the $g f p$ gene was calculated based on the size of vector $(2.8 \mathrm{kbp})$ and the size of gene $(720 \mathrm{bp})$. Thus, $10 \mathrm{ng}$ of the plasmid contained $2.57 \mathrm{ng}$ of $g f p$. An appropriate amount of plasmid was used to yield $10 \mathrm{ng}$ of $g f p$ and then five 10-fold serial dilutions were used in order to produce the template for a standard curve. The standard curves were obtained by linear regression analysis of the threshold cycle $(\mathrm{Ct})$ value of each of the three standard-dilution replicates over the log of the total DNA amount present in each sample. Data acquisition and analysis used the Bio-Rad iCycler software (version 3.06070) that calculates the $\mathrm{Ct}$ values, all the parameters of the standard curves, and the corresponding dissociation curves for each sample. qPCR reactions were carried out as described previously (Azhar et al. 2010). All reactions were repeated three times independently to ensure the reproducibility of the results. For each (qPCR) run, standards were loaded on the same plate to produce the appropriate standard curve.

\section{Expression of viral proteins and in vitro RNA binding assays.}

Viral and satellite genes encoding putative suppressors of silencing ( $\beta \mathrm{C} 1, \mathrm{C} 2, \mathrm{C} 4$, and $\mathrm{V} 2)$ and Cymbidium ringspot virus (CymRSV) P19 were PCR amplified using specific sets of primers and cloned into the pEXP5-TN/TOPO vector (Invitrogen Life Technologies). No viable transformants were obtained for insertion of the $\mathrm{C} 2$ gene upon transformation into $E$. coli. The remaining three genes were expressed in E. coli BL21 and the proteins purified by using 6X His-tag binding resin $(\mathrm{Ni}-$ NTA; Qiagen, Basel, Switzerland) as described by the manufacturer. Following purification, the proteins were used in in vitro RNA-binding assays after quantification by Bradford assay (Bradford 1976). The interaction of various RNAs with silencing suppressors was determined by incubating proteins with radioactively labeled long and short ss and dsRNA before immobilizing on nitrocellulose filters $(0.22 \mu \mathrm{m}$; Millipore, 
Beverly, MA, U.S.A.) and washing to remove unbound RNA. The standard 20- $\mu$ l reaction mixture contained $25 \mathrm{mM}$ HEPES-KOH (pH 7.6), $1 \mathrm{mM}$ MET, $100 \mathrm{mM} \mathrm{KCl,} 0.2 \mathrm{mM}$ GTP, $1 \mathrm{mM}$ ATP, $4 \mu \mathrm{g}$ of bovine serum albumin (BSA), and 1 $\mu \mathrm{g}$ of purified protein. For long ssRNA, 100,000 counts per minute (CPM) of ${ }^{33} \mathrm{P}$-labeled GFP RNA (a full-length GFP transcript of approximately 718 nucleotides) was added to the reaction mixture. For binding of long dsRNA, 100,000 CPM of ${ }^{33} \mathrm{P}$-labeled full-length GFP transcript (ssRNA) was annealed with $0.3 \mu \mathrm{g}$ of complementary nonlabeled RNA. Assays for short ssRNA binding used $0.1 \mu \mathrm{g}$ of ${ }^{32} \mathrm{P}$ end-labeled miR173 (arbitrarily chosen as representative of small RNAs). For short dsRNA, binding $0.1 \mu \mathrm{g}$ of ${ }^{32} \mathrm{P}$ end-labeled miR173 was annealed with $0.1 \mu \mathrm{g}$ of nonlabeled miR173*. After $15 \mathrm{~min}$ of incubation at $25^{\circ} \mathrm{C}$, the reaction was stopped by dilution in $1 \mathrm{ml}$ of cold buffer (without GTP, ATP, and BSA), filtered, and washed three times with $5 \mathrm{ml}$ of cold buffer. Filters were dried and the retained radioactivity was measured in a liquid scintillation counter.

\section{ACKNOWLEDGMENTS}

K. Hussain was supported by a Ph.D. fellowship from the Higher Education Commission (HEC), Government of Pakistan. R. W. Briddon is supported by the HEC under the "Foreign Faculty Hiring Program". R. Akbergenov was supported by the Marie Curie Foundation within the EU VI framework. The work in Pakistan and the United States has been supported by projects from the Ministry of Science and Technology, Government of Pakistan, and a project between NIBGE and Donald Danforth Plant Science Center under the Pakistan-U.S. linkage program. The work in Switzerland was supported by a grant from the HEC under the International Research Support Initiative Program and by a short-term fellowship from the European Molecular Biology Organization (EMBO) to $\mathrm{K}$. Hussain, and a grant of the Swiss National Fonds to T. Hohn. We thank P. Moffett (Boyce Thompson Institute for Plant Research) for the 35S driven HC-Pro, P19, and TCV-CP constructs; T. Mustafa (NIBGE) for advice on statistical analysis of the results; and T. Boller, A. Wimken, and C. Koerner for infrastructure and support in Switzerland.

\section{LITERATURE CITED}

Akbergenov, R., Si-Ammour, A., Blevins, T., Amin, I., Kutter, C., Vanderschuren, H., Zhang, P., Gruissem, W., Meins, F., Jr., Hohn, T., and Pooggin, M. M. 2006. Molecular characterization of geminivirusderived small RNAs in different plant species. Nucleic Acids Res. $34: 462-471$

Amin, I., Ilyas, M., Qazi, J., Bashir, R., Yadav, J. S., Mansoor, S., Fauquet, C. M., and Briddon, R. W. 2011. Identification of a major pathogenicity determinant and suppressors of RNA silencing encoded by a South Pacific isolate of Banana bunchy top virus originating from Pakistan. Virus Genes. 42:272-281.

Amrao, L., Amin, I., Shahid, M. S., Briddon, R. W., and Mansoor, S. 2010. Cotton leaf curl disease in resistant cotton is associated with a single begomovirus that lacks an intact transcriptional activator protein. Virus Res. 152, 153-163.

Anandalakshmi, R., Pruss, G. J., Ge, X., Marathe, R., Mallory, A. C., Smith, T. H., and Vance, V. B. 1998 A viral suppressor of gene silencing in plants. Proc. Natl. Acad. Sci. U.S.A. 95:13079-13084.

Azhar, M. T., Amin, I., Anjum, Z. I., Arshad, M., Briddon, R. W., and Mansoor, S. 2010. Both malvaceous and non-malvaceous betasatellites are associated with two wild cotton species grown under field conditions in Pakistan. Virus Genes 41:417-424.

Baulcombe, D. 2004. RNA silencing in plants. Nature 431:356-363.

Baulcombe, D. C. 1996 Mechanisms of pathogen-derived resistance to viruses in transgenic plants. Plant Cell 8:1833-1844.

Bisaro, D. M. 2006. Silencing suppression by geminivirus proteins. Virology $344: 158-168$

Bradford, M. M. 1976. A rapid and sensitive method for the quantitation of microgram quantities of protein utilizing the principle of protein-dye binding. Anal. Biochem. 72:248-254.

Briddon, R. W., and Markham, P. G. 2001. Cotton leaf curl virus disease. Virus Res. 71:151-159.

Briddon, R. W., and Stanley, J. 2006 Sub-viral agents associated with plant-infecting single-stranded DNA viruses. Virology 344:198-210.
Briddon, R. W., Mansoor, S., Bedford, I. D., Pinner, M. S., and Markham, P. G. 2000. Clones of cotton leaf curl geminivirus induce symptoms atypical of cotton leaf curl disease. Virus Genes 20:17-24.

Briddon, R. W., Mansoor, S., Bedford, I. D., Pinner, M. S., Saunders, K., Stanley, J., Zafar, Y., Malik, K. A., and Markham, P. G. 2001. Identification of DNA components required for induction of cotton leaf curl disease. Virology 285:234-243.

Briddon, R. W., Bull, S. E., Amin, I., Mansoor, S., Bedford, I. D., Dhawan, P., Rishi, N., Siwatch, S. S., Abdel-Salam, A. M., and Markham, P. G. 2003. Diversity of DNA $\beta$ : A satellite molecule associated with some monopartite begomoviruses. Virology 312:106-121.

Briddon, R. W., Bull, S. E., Amin, I., Mansoor, S., Bedford, I. D., Rishi, N., Siwatch, S. S., Zafar, Y., Abdel-Salam, A. M., and Markham, P. G. 2004. Diversity of DNA 1: A satellite-like molecule associated with monopartite begomovirus-DNA $\beta$ complexes. Virology 324:462-474.

Brigneti, B., Voinnet, O., Li, W.-X., Ji, L.-H., Ding, S.-W., and Baulcombe, D. C. 1998 Viral pathogenicity determinants are suppressors of transgene silencing in Nicotiana benthamiana. EMBO (Eur. Mol. Biol. Organ.) J. 17:6739-6746.

Bull, S. E., Briddon, R. W., Sserubombwe, W. S., Ngugi, K., Markham, P. G., and Stanley, J. 2007. Infectivity, pseudorecombination and mutagenesis of Kenyan cassava mosaic begomoviruses. J. Gen. Virol. 88:1624-1633.

Burgyan, J. 2008. Role of silencing suppressor proteins. Methods Mol. Biol. 451:69-79.

Chellappan, P., Vanitharani, R., and Fauquet, C. M. 2005. MicroRNAbinding viral protein interferes with Arabidopsis development. Proc. Natl. Acad. Sci. U.S.A. 102:10381-10386.

Cui, X., Li, G., Wang, D., Hu, D., and Zhou, X. 2005. A begomovirus DNA $\beta$-encoded protein binds DNA, functions as a suppressor of RNA silencing, and targets the cell nucleus. J. Virol. 79:10764-10775.

Ding, S.-W., Li, H., Lu, R., Li, F., and Li, W.-X. 2004. RNA silencing: A conserved antiviral immunity of plants and animals. Virus Res. 102:109-115

Dry, I., Krake, L., Mullineaux, P., and Rezaian, A. 2000. Regulation of tomato leaf curl viral gene expression in host tissues. Mol. PlantMicrobe Interact. 13:529-537.

Fondong, V. N., Pita, J. S., Rey, C., Beachy, R. N., and Fauquet, C. M. 1998. First report of east African cassava mosaic virus in Cameroon. Plant Dis. 82:1172.

Fondong, V. N., Pita, J. S., Rey, M. E. C., de Kochko, A., Beachy, R. N., and Fauquet, C. M. 2000. Evidence for synergism between African cassava mosaic virus and a new double-recombinant geminivirus infecting cassava in Cameroon. J. Gen. Virol. 81:287-297.

Fukunaga, R., and Doudna, J. A. 2009. dsRNA with 5' overhangs contributes to endogenous and antiviral RNA silencing pathways in plants. EMBO (Eur. Mol. Biol. Organ.) J. 28:545-555.

Gibson, R. W., and Otim-Nape, G. W. 1997. Factors determining recovery and reversion in mosaic-affected African cassava mosaic virus resistant cassava. Ann. Appl. Biol. 131:259-271.

Gilbertson, R. L., Sudarshana, M., Jiang, H., Rojas, M. R., and Lucas, W. J. 2003. Limitations on geminivirus genome size imposed by plasmodesmata and virus-encoded movement protein: Insights into DNA trafficking. Plant Cell 15:2578-2591.

Gopal, P., Pravin Kumar, P., Sinilal, B., Jose, J., Kasin Yadunandam, A., and Usha, R. 2007. Differential roles of $\mathrm{C} 4$ and $\beta C 1$ in mediating suppression of post-transcriptional gene silencing: Evidence for transactivation by the $\mathrm{C} 2$ of Bhendi yellow vein mosaic virus, a monopartite begomovirus. Virus Res. 123:9-18.

Guerineau, F., Lucy, A., and Mullineaux, P. 1992. Effect of two consensus sequences preceding the translation initiator codon on gene expression in plant protoplasts. Plant Mol. Biol. 18:815-818.

Hanley-Bowdoin, L., Settlage, S. B., Orozco, B. M., Nagar, S., and Robertson, D. 1999. Geminviruses: Models for plant DNA replication, transcription, and cell cycle regulation. Crit. Rev. Plant Sci. 18:71-106.

Harrison, B. D., Liu, Y. L., Khalid, S., Hameed, S., Otim-Nape, G. W., and Robinson, D. J. 1997 Detection and relationships of cotton leaf curl virus and allied whitefly-transmitted geminiviruses occurring in Pakistan. Ann. Appl. Biol. 130:61-75.

Haseloff, J., Siemering, K. R., Prasher, D. C., and Hodge, S. 1997. Removal of a cryptic intron and subcellular localization of green fluorescent protein are required to mark transgenic Arabidopsis plants brightly. Proc. Natl. Acad. Sci. U.S.A. 94:2122-2127.

Hellens, R. P., Edwards, E. A., Leyland, N. R., Bean, S., and Mullineaux, P. M. 2000. pGreen: A versatile and flexible binary Ti vector for Agrobacterium-mediated plant transformation. Plant Mol. Biol. 42:819-832.

Hong, Y., Saunders, K., and Stanley, J. 1997. Transactivation of dianthin transgene expression by African cassava mosaic virus AC2. Virology 228:383-387.

Hussain, M., Mansoor, S., Iram, S., Zafar, Y., and Briddon, R. W. 2007. 
The hypersensitive response to Tomato leaf curl New Delhi virus nuclear shuttle protein is inhibited by transcriptional activator protein. Mol. Plant-Microbe Interact. 20:1581-1588.

Hussain, T., and Ali, M. 1975. A review of cotton diseases of Pakistan. Pak. Cotton 19:71-86.

Idris, A. M., Shahid, M. S., Briddon, R. W., Khan, A. J., Zhu, J.-K., and Brown, J. K. 2011. An unusual alphasatellite associated with monopartite begomoviruses attenuates symptoms and reduces betasatellite accumulation. J. Gen. Virol.92:706-717.

Jose, J., and Usha, R. 2003. Bhendi yellow vein mosaic disease in India is caused by association of a DNA $\beta$ satellite with a begomovirus. Virology 305:310-317.

Kasschau, K. D., and Carrington, J. C. 1998. Suppression of posttranscriptional gene silencing. Cell 95:461-470.

Kerschen, A., Napoli, C. A., Jorgensen, R. A., and Muller, A. E. 2004. Effectiveness of RNA interference in transgenic plants. FEBS (Fed. Eur. Biochem. Soc.) Lett. 566:223-228.

Kon, T., Sharma, P., and Ikegami, M. 2007. Suppressor of RNA silencing encoded by the monopartite tomato leaf curl Java begomovirus. Arch. Virol. 152:1273-1282.

Lakatos, L., Szittya, G., Silhavy, D., and Burgyan, J. 2004. Molecular mechanism of RNA silencing suppression mediated by p19 protein of tombusviruses. EMBO (Eur. Mol. Biol. Organ.) J. 23:876-884.

Li, F., and Ding, S.-W. 2006. Virus counterdefense: Diverse strategies for evading the RNA-silencing immunity. Annu. Rev. Microbiol. 60:503531

Llave, C., Kasschau, K., and Carrington, J. C. 2000. Virus-encoded suppressor of posttranscriptional gene silencing targets a maintenance step in the silencing pathway. Proc. Natl. Acad. Sci. U.S.A. 97:1340113406.

Lu, R., Folimonov, A., Shintaku, M., Li, W.-X., Falk, B. W., Dawson, W. O., and Ding, S.-W. 2004. Three distinct suppressors of RNA silencing encoded by a $20-\mathrm{kb}$ viral RNA genome. Proc. Natl. Acad. Sci. U.S.A. 101:15742-15747.

Mansoor, S., Bedford, I., Pinner, M. S., Stanley, J., and Markham, P. G. 1993 A whitefly-transmitted geminivirus associated with cotton leaf curl disease in Pakistan. Pak. J. Bot. 25:105-107.

Mansoor, S., Khan, S. H., Bashir, A., Saeed, M., Zafar, Y., Malik, K.A., Briddon, R. W., Stanley, J., and Markham, P. G. 1999. Identification of a novel circular single-stranded DNA associated with cotton leaf curl disease in Pakistan. Virology 259:190-199.

Mansoor, S., Amin, I., Iram, S., Hussain, M., Zafar, Y., Malik, K.A., and Briddon, R.W. 2003a. Breakdown of resistance in cotton to cotton leaf curl disease in Pakistan. Plant Pathol. 52:784.

Mansoor, S., Briddon, R. W., Bull, S. E., Bedford, I. D., Bashir, A., Hussain, M., Saeed, Zafar, M. Y., Malik, K. A., Fauquet, C., and Markham, P. G. 2003b. Cotton leaf curl disease is associated with multiple monopartite begomoviruses supported by single DNA $\beta$. Arch. Virol. 148:1969-1986.

Muniyappa, V. 1980. Whiteflies. Pages 39-85 in: Vectors of Plant Pathogens. K. F. Harris and K. Maramorosch, eds. Academic Press, New York.

Nawaz-ul-Rehman, M. S., Mansoor, S., Briddon, R. W., and Fauquet, C. M. 2009. Maintenance of an Old World betasatellite by a New World helper begomovirus and possible rapid adaptation of the betasatellite. J. Virol. 83:9347-9355.

Nawaz-ul-Rehman, M. S., Nahid, N., Mansoor, S., Briddon, R. W., and Fauquet, C. M. 2010. Post-transcriptional gene silencing suppressor activity of the alpha-Rep of non-pathogenic alphasatellites associated with begomoviruses. Virology 405:300-308.

Padidam, M., Beachy, R. N., and Fauquet, C. M. 1996. The role of AV2 ("precoat") and coat protein in viral replication and movement in tomato leaf curl geminivirus. Virology 224:390-404.

Rajeswaran, R., Sunitha, S., Shivaprasad, P. V., Pooggin, M. M., Hohn, T., and Veluthambi, K. 2007. The mungbean yellow mosaic begomovirus transcriptional activator protein transactivates the viral promoter-driven transgene and causes toxicity in transgenic tobacco plants. Mol. PlantMicrobe Interact. 20:1545-1554.

Rigden, J. E., Dry, I. B., Mullineaux, P. M., and Rezaian, M. A. 1993. Mutagenesis of the virion-sense open reading frames of tomato leaf curl virus. Virology 193:1001-1005.

Rojas, A., Kvarnheden, A., Marcenaro, D., and Valkonen, J. P. T. 2005. Sequence characterization of Tomato leaf curl Sinaloa virus and Tomato severe leaf curl virus: Phylogeny of New World begomoviruses and detection of recombination. Arch. Virol. 150:1281-1299.

Rojas, M. R., Jiang, H., Salati, R., Xoconostle-Cazares, B., Sudarshana, M. R., Lucas, W. J., and Gilbertson, R. L. 2001. Functional analysis of proteins involved in movement of the monopartite begomovirus, Tomato yellow leaf curl virus. Virology 291:110-125.

Roth, B. M., Pruss, G. J., and Vance, V. B. 2004. Plant viral suppressors of RNA silencing. Virus Res. 102:97-108.

Ruiz, T. M., Voinnet, O., and Baulcombe, D. C. 1998. Initiation and maintenance of virus-induced gene silencing. Plant Cell 10:937-946.

Saeed, M., Behjatania, S. A. A., Mansoor, S., Zafar, Y., Hasnain, S., and Rezaian, M. A. 2005. A single complementary-sense transcript of a geminiviral DNA $\beta$ satellite is determinant of pathogenicity. Mol. PlantMicrobe Interact. 18:7-14.

Saunders, K., and Stanley, J. 1999. A nanovirus-like component associated with yellow vein disease of Ageratum conyzoides: Evidence for interfamilial recombination between plant DNA viruses. Virology 264:142152.

Saunders, K., Bedford, I. D., Briddon, R. W., Markham, P. G., Wong, S. M., and Stanley, J. 2000. A novel virus complex causes Ageratum yellow vein disease. Proc. Natl. Acad. Sci. U.S.A. 97:6890-6895.

Saunders, K., Norman, A., Gucciardo, S., and Stanley, J. 2004. The DNA $\beta$ satellite component associated with ageratum yellow vein disease encodes an essential pathogenicity protein $(\beta C 1)$. Virology 324:37-47.

Sharma, P., and Ikegami, M. 2008. RNA-silencing suppressors of geminiviruses. J. Gen. Plant Pathol. 74:189-202.

Stanley, J., Bisaro, D. M., Briddon, R. W., Brown, J. K., Fauquet, C. M., Harrison, B. D., Rybicki, E. P., and Stenger, D. C. 2005. Geminiviridae. Pages 301-326 in: Virus Taxonomy, VIIIth Report of the ICTV. C. M. Fauquet, M. A. Mayo, J. Maniloff, U. Desselberger, and L. A. Ball, eds. Elsevier/Academic Press, London.

Sunter, G., and Bisaro, D. M. 1992. Transactivation of geminivirus AR1 and BR1 gene expression by the viral AL2 gene product occurs at the level of transcription. Plant Cell 4:1321-1331.

Thomas, C. L., Leh, V., Lederer, C., and Maule, A. J. 2003. Turnip crinkle virus coat protein mediates suppression of RNA silencing in Nicotiana benthamiana. Virology 306:33-41.

Trinks, D., Rajeswaran, R., Shivaprasad, P. V., Akbergenov, R., Oakeley, E. J., Veluthambi, K., Hohn, T., and Pooggin, M. M. 2005. Suppression of RNA silencing by a geminivirus nuclear protein, AC2, correlates with transactivation of host genes. J. Virol. 79:2517-2527.

Vanitharani, R., Chellappan, P., Pita, J. S., and Fauquet, C. M. 2004. Differential roles of AC2 and AC4 of cassava geminiviruses in mediating synergism and suppression of posttranscriptional gene silencing. J. Virol. 78:9487-9498.

van Wezel, R., Dong, X., Blake, P., Stanley, J., and Hong, Y. 2002. Differential roles of geminivirus Rep and AC4 (C4) in the induction of necrosis in Nicotiana benthamiana. Mol. Plant Pathol. 3:461-471.

Varma, A., and Malathi, V. G. 2003. Emerging geminivirus problems: A serious threat to crop production. Ann. Appl. Biol. 142:145-164.

Voinnet, O. 2005. Induction and suppression of RNA silencing: Insights from viral infections. Nat. Rev. Genet. 6:206-220.

Voinnet, O., Rivas, S., Mestre, P., and Baulcombe, D. 2003. An enhanced transient expression system in plants based on suppression of gene silencing by the p19 protein of Tomato bushy stunt virus. Plant J. 33:949-956.

Wang, H., Buckley, K. J., Yang, X., Buchmann, R. C., and Bisaro, D. M. 2005. Adenosine kinase inhibition and suppression of RNA silencing by geminivirus AL2 and L2 proteins. J. Virol. 79:7410-7418.

Wartig, L., Kheyr-Pour, A., Noris, E., de Kouchovsky, F., Jouanneau, F., Gronenborn, B., and Jupin, I. 1997. Genetic analysis of the monopartite tomato yellow leaf curl geminivirus: Roles of V1, V2, and C2 ORFs in viral pathogenesis. Virology 228:132-140

Zrachya, A., Glick, E., Levy, Y., Arazi, T., Citovsky, V., and Gafni, Y. 2007. Suppressor of RNA silencing encoded by Tomato yellow leaf curl virusIsrael. Virology 358:159-165. 